\title{
ANALISIS KEPEMILIKAN JAMBAN SEHAT PADA MASYARAKAT TEPI SUNGAI DI KOTA BANJARMASIN (STUDI DI RT 01 KELURAHAN ALALAK UTARA)
}

\author{
Analysis on Ownership of Hygienic Latrine amongst Riverbank Community in Banjarmasin City \\ (Study in RT 01 Kelurahan Alalak Utara) \\ Meilya Farika Indah , Asrinawaty , Noor Azizah Nopeana \\ Fakultas Kesehatan Masyarakat Universitas Islam Kalimantan MAB Banjarmasin \\ Email:meifkm@gmail.com
}

\begin{abstract}
The habit of the members of riverbank community to defecate in the river, make them reluctant to make their own lantrine in their own house. Preliminary study shows that the community in RT 01 Kelurahan Alalak Utara still use pit latrine that directly connected to river to discard their waste. The objective of this study is to analyze the ownership of hygienic latrine amongst riverbank community in RT 01 Kelurahan Alalak as work area of Alalak Tengah Public Health Center in Banjarmasin. This study uses analytic survey method with cross sectional study approach. The population is all heads of family in RT 01 Kelurahan Alalak Utara, consisting of 187 families. Simple random sampling is used to select 65 respondents as the samples. Data analysis uses chi-square method with $95 \%$ reliability. The result shows that there are significant relationships between knowledge ( $p$ value 0.001), attitude ( $p$ value 0.000), education level ( $p$ alue 0,000), economic status ( $p$ value 0.000) with the ownership of hygienic latrine. There is no relationship between officer role ( $p$ value 0.07 ) with the ownership of hygienic latrine. It is suggested that both health officers and community to be more actively involved in enhancing environmental health by constructing hygienic latrine and increasing awareness of the importance of having healthy latrines
\end{abstract}

Keywords : Divorce, Parental divorce, Adolescent, Grieving Response

\begin{abstract}
Abstrak
Budaya masyarakat tepi sungai yang lebih suka membuang air besar (BAB) di sungai, membuat mereka enggan membuat jamban di rumah masing-masing. Berdasarkan studi awal menunjukkan sebagian besar masyarakat di RT 01 kelurahan Alalak Utara masih menggunakan jamban cemplung untuk buang air besar/kecil dan limbah rumah tangganya langsung dialirkan ke sungai. Data Puskesmas Alalak Tengah tahun 2017 di kelurahan Alalak Utara menunjukkan jamban keluarga yang terinspeksi sebanyak 626 buah dan hanya 587 buah yang memenuhi syarat atau $14,1 \%$. Tujuan penelitian ini untuk menganalisis kepemilikan jamban sehat pada masyarakat pinggiran sungai di RT 01 kelurahan Alalak Utara wilayah kerja Puskesmas Alalak Tengah kota Banjarmasin. Metode penelitian dalam penelitian ini yaitu survei analitik dengan pendekatan cross sectional study. Populasi adalah seluruh kepala keluarga di RT 01 kelurahan Alalak Utara, yaitu sebanyak 187 kepala keluarga. Sampel penelitian menggunakan teknik simple random sampling, berjumlah 65 responden. Analisis data menggunakan uji chi-square dengan tingkat kepercayaan sebesar 95\%. Hasil penelitian menunjukkan bahwa ada hubungan yang signifikan antara pengetahuan ( $p$ value 0,001 ), sikap ( $p$ value 0,000 ), tingkat pendidikan ( $p$ value 0,000$)$, status ekonomi ( $p$ value 0,000 ) dengan kepemilikan jamban sehat, tidak ada hubungan antara peran petugas ( $p$ value 0,07 ) dengan kepemilikan jamban sehat. Disarankan agar masyarakat bersama-sama petugas kesehatan lebih berperan aktif dalam menjaga kesehatan lingkungan yaitu dengan cara membangun jamban sehat dan meningkatkan kesadaran akan pentingnya memiliki jamban sehat..
\end{abstract}

Kata Kunci : kepemilikan, jamban sehat, pengetahuan, sikap, tingkat pendidikan, status ekonomi, peran petugas, tepi sungai 


\section{PENDAHULUAN}

Derajat kesehatan merupakan salah satu faktor yang sangat berpengaruh pada kualitas sumber daya manusia yang akan lebih produktif dan meningkatkan daya saing manusia. Masalah kondisi lingkungan tempat pembungan kotoran manusia tidak terlepas dari aspek kepemilikan terhadap sarana yang digunakan. Berdasarkan data dari World Health Organization (WHO) pada tahun 2013 diperkirakan sebesar 1,1 milyar orang atau 17\% penduduk dunia masih Buang Air Besar (BAB) di area terbuka. Dari data tersebut sebesar $81 \%$ penduduk yang Buang Air Besar Sembarangan (BABS) terdapat di 10 negara, Indonesia sebagai negara kedua terbanyak ditemukan masyarakat ODF (Open Defecation Free), yaitu India (58\%), Indonesia $(12,9 \%)$, China $(4,5 \%)$, Nepal (1,3\%), Brazil (1,2\%), dan Nigeria $(1,1 \%)(\mathrm{WHO}, 2014)$.

Buang air besar sembarangan merupakan salah satu permasalahan kesehatan di Indonesia untuk meningkatkan derajat kesehatan masyarakat dimana yang menjadi tantangannya adalah masalah sosial budaya. Budaya masyarakat yang lebih suka membuang air besar (BAB) disembarangan tempat membuat mereka enggan membuat jamban dirumah masing-masing, berdasarkan konsep dan definisi Millenium Development Goals (MDGs) yang pada tahun 2016 dilanjutkan dengan Sustainable Development Goals (SDGs), rumah tangga dikatakan memiliki akses sanitasi yang layak apabila sanitasi yang digunakan memenuhi syarat kesehatan antara lain dilengkapi dengan leher angsa, tanki septik (septic tank) / Sistem Pengolahan Air Limbah (SPAL) yang digunakan sendiri atau bersama. Persentase rumah tangga di Indonesia yang memiliki akses terhadap sanitasi layak tahun 2013 yaitu 60,05\% dan meningkat pada tahun 2014 menjadi 61,08\% dan pada tahun 2015 meningkat 62,14\% (Kemenkes RI, 2016).

Masalah pembuangan kotoran manusia merupakan masalah yang pokok untuk sedini mungkin diatasi. Karena kotoran manusia (Feces) adalah sumber penyebaran penyakit yang mutikompleks. Beberapa penyakit yang dapat disebarkan oleh tinja manusia antara lain tifus, disentri, kolera, bermacam-macam cacing (gelang, kremi, tambang, pita), schitosomiasis (Notoatmodjo, 2011).

Dari survei pendahuluan menunjukkan bahwa sebagian besar masyarakat di RT 01 kelurahan Alalak Utara wilayah kerja Puskesmas Alalak Tengah masih menggunakan jamban cemplung untuk buang air besar/kecil dan limbahnya langsung dialirkan ke sungai. Sebagian masyarakat disana masih belum memiliki jamban yang memenuhi syarat sehat dan mereka masih menggunakan air sungai untuk mandi, mencuci pakaian maupun peralatan dapur, termasuk mencuci kendaraan bermotornya. Hal ini dikarenakan kebiasaan yang sudah turun temurun dan mereka menganggap sudah kebal terhadap penyakit yang diakibatkan oleh penggunaan air sungai.

Berdasarkan data profil Puskesmas Alalak Tengah tahun 2017 menunjukkan bahwa permasalahan mengenai jamban sehat yang ada di masyarakat pinggiran sungai mesti harus diperhatikan secara serius, itu di buktikan dari data profil Puskesmas Alalak Tengah tahun 2017 yang menunjukkan bahwa 339 jamban yang memenuhi syarat atau sekitar 20,4\% dari 417 jumlah jamban keluarga yang diinspeksi dengan total jamban yang berada di wilayah tersebut berjumlah 1.662 buah jamban keluarga yang berada di wilayah kelurahan Alalak Tengah. Sedangkan untuk di kelurahan Alalak Utara, dari total jamban keluarga yaitu 4.166 buah jamban keluarga. Untuk yang terinspeksi 626 buah jamban keluarga dan hanya 587 buah jamban keluarga yang memenuhi syarat atau dengan presentase $14,1 \%$.

Tujuan dari penelitian ini yaitu menganalisis kepemilikan jamban sehat pada masyarakat pinggiran sungai di RT 01 kelurahan Alalak Utara wilayah kerja Puskesmas Alalak Tengah kota Banjarmasin, dengan meneliti variable penelitian yang meliputi pengetahuan, sikap, tingkat pendidikan, status ekonomi, dan peran petugas yang dihubungkan dengan kepemilikan jamban sehat

\section{BAHAN DAN METODE}

Metode penelitian yang digunakan adalah survey analitik dengan pendekatan cross sectonal, 
Penelitian ini dilakukan pada bulan Juli 2018, populasi penelitian ini adalah seluruh kepala keluarga yang bertempat tinggal di RT 01 Kelurahan Alalak Utara wilayah kerja Puskesmas Alalak Tengah berjumlah 187 kepala keluarga (KK) dengan sampel 65 orang dengan teknik pengambilan sampel yang digunakan Simple random sampling atau populasi yang diambil secara acak sederhana. Instrumen yang digunakan yaitu kuesioner dan formulir observasi dengan variabel independen adalah pengetahuan, sikap, tingkat pendidikan, status ekonomi, dan peran petugas sedangkan variabel terikat adalah kepemilikan jamban sehat. Metode pengolahan data melalui tahap Editing, Coding, Tabulating, Entry, Cleaning kemudian dianalisis secara statistik menjadi dua bagian yaitu analisis univariat dan analisis bivariat.

\section{HASIL DAN PEMBAHASAN}

Secara geografis Puskesmas Alalak Tengah terletak di Kecamatan Banjarmasin Utara Kota Banjarmasin, dan terdiri dari dua kelurahan yaitu kelurahan alalak tengah dan utara. Lokasi penelitian ini yaitu pada kelurahan alalak utara di RT 01 dengan jumlah responden sebanyak 65 orang. Berikut ini merupakan tabel karakteristik responden berdasarkan jenis kelamin, usia dan pekerjaan.

Tabel 1. Distribusi Frekuensi Karakteristik

\begin{tabular}{lcc}
\multicolumn{3}{c}{ Responden } \\
\hline Karakteristik & $\mathbf{n}$ & $\%$ \\
\hline Jenis Kelamin & & \\
$\quad$ Laki-laki & 54 & 83.1 \\
$\quad$ Perempuan & 11 & 16.9 \\
Usia & & \\
$25-35$ & 19 & 29.2 \\
$36-45$ & 21 & 32.3 \\
$46-55$ & 14 & 21.5 \\
$56-65$ & 7 & 10.8 \\
$>65$ & 4 & 6.2 \\
Pekerjaan & & \\
Buruh & 34 & 52.3 \\
Wiraswasta & 16 & 24.6 \\
PNS & 2 & 3.1 \\
Lain-Lain & 13 & 20 \\
\hline Total & $\mathbf{6 5}$ & $\mathbf{1 0 0}$ \\
\hline
\end{tabular}

Berdasarkan Tabel 1. menunjukkan sebagian besar responden berjenis kelamin laki-laki yaitu sebanyak 54 orang $(83,1 \%)$, dan 11 orang $(16,9 \%)$ berjenis kelamin perempuan, dan berusia paling banyak pada interval usia 36-45 tahun sebanyak 21 orang $(32,2 \%)$ dan sebagian besar bekerja sebagai buruh sebanyak 34 orang $(52,3 \%)$.

\section{Analisis Univariat}

Di bawah ini merupakan tabel analisis univariat yaitu sebagai berikut:

Tabel 2. Distribusi Frekuensi Variabel Penelitian

\begin{tabular}{lcc}
\hline Variabel Pengetahuan & N & \% \\
$\quad$ Baik & 29 & 44.6 \\
Cukup & 33 & 50.8 \\
Kurang & 3 & 4.6 \\
Sikap & & \\
$\quad$ Positif & 40 & 61.5 \\
$\quad$ Negatif & 25 & 38.5 \\
Tingkat pedidikan & & \\
$\quad$ Dasar & 46 & 70.8 \\
$\quad$ Menengah & 17 & 26.2 \\
$\quad$ Tinggi & 2 & 3.1 \\
Status ekonomi & & \\
$\quad$ Tinggi >UMK & 21 & 32.3 \\
$\quad$ Rendah <UMK & 44 & 67.7 \\
Peran petugas & & \\
$\quad$ Aktif & 19 & 29.2 \\
$\quad$ Tidak aktif & 46 & 70.8 \\
Kepemilikan jamban sehat & & \\
$\quad$ Jamban sehat & 18 & 27.7 \\
$\quad$ Tidak memenuhi syarat & 26 & 40 \\
$\quad$ Tidak memiliki jamban & 21 & 32.3 \\
\hline$\quad$ Total & 65 & $\mathbf{1 0 0}$ \\
\hline
\end{tabular}

Hasil penelitian didapatkan bahwa dari 65 responden yang memiliki jamban tidak memenuhi syarat kesehatan berjumlah 26 responden (40\%), tidak memiliki jamban keluarga 21 responden $(32,3 \%)$, dan memiliki jamban sehat 18 responden $(32,3 \%)$.

Masih banyaknya responden yang belum memiliki jamban yang memenuhi syarat sehat. Sebagian besar jamban tidak memiliki septic tank, bangunannya belum permanen, lantai tidak kedap air dan kurangnya penerangan. Responden masih banyak yang menggunakan jamban di pinggiran sungai sehingga berpotensi mencemari lingkungan khususnya sungai. 
Untuk pengetahuan responden, hasil penelitian menunjukkan bahwa sebagian besar responden berpengetahuan cukup berjumlah 33 responden $(50,8 \%)$, dan yang berpengetahuan baik berjumlah 29 responden $(4,6 \%)$, sedangkan responden yang berpengetahuan kurang berjumlah 3 responden $(4,6 \%)$. Untuk sikap responden sebagian besar memiliki sikap positif yaitu sebanyak 40 responden $(61,5 \%)$, dan memiliki sikap negatif berjumlah 25 responden $(38,5 \%)$.

Pengetahuan adalah merupakan hasil "tahu" dan ini terjadi setelah seseorang melakukan penginderaan terhadap suatu objek tertentu. Dari pengalaman dan penelitian terbukti bahwa perilaku yang didasari oleh pengetahuan akan lebih sempurna dari pada perilaku yang tidak didasari oleh pengetahuan. (Notoatmodjo, 2011). Sikap merupakan reaksi atau respon seseorang yang masih tertutup terhadap suatu stimulus atau objek, dalam kehidupan sehari-hari merupakan reaksi yang bersifat emosional terhadap stimulus sosial (Notoatmodjo, 2011).

Hasil penelitian ini menunjukkan bahwa sebagian besar responden dengan tingkat pendidikan dasar berjumlah 46 responden $(70,8 \%)$, tingkat pendidikan menengah berjumlah 10 responden $(26,2 \%)$, dan tingkat pendidikan tinggi 2 responden $(3,1 \%)$. Pendidikan adalah perubahan sikap dan perilaku serta penambahan ilmu pengetahuan, pendidikan akan berhasil dengan baik bila disertai dengan tujuan, melalui proses pendidikan pengalaman seseorang perubahan tingkah laku dalam melaksanakan aktivitas seharihari. Semakin tinggi pendidikan masyarakat maka semakin baik tingkah laku serta bertambah wawasan terhadap kepemilikan jamban sehat (Azwar, 2003).

Untuk status ekonomi responden menunjukkan bahwa sebagian besar responden dengan Status ekonomi Rendah berjumlah 44 responden $(67,7 \%)$, dan dengan Status ekonomi tinggi 21 responden $(32,3 \%)$. Faktor ekonomi sangat mempengaruhi dalam penyediaan fasilitas kesehatan. Tingginya angka jamban yang tidak memenuhi syarat sehat, bahkan tidak memiliki jamban masih tinggi dibandingkan yang memiliki jamban sehat salah satu faktor yang mempengaruhinya yaitu status ekonomi yang rendah. Ekonomi adalah adanya ketidakseimbangan antara kebutuhan manusia yang tidak terbatas dengan alat pemuas kebutuhan yang jumlahnya terbatas.

Untuk peran petugas menunjukkan bahwa sebagian besar responden menilai peran petugas tidak aktif dalam melakukan penyuluhan berjumlah 46 responden $(70,8 \%)$, dan menilai peran petugas aktif dalam melakukan penyuluhan berjumlah 19 responden $(29,2 \%)$. Perilaku kesehatan seseorang atau masyarakat ditentukan juga dari ada tidaknya informasi kesehatan. Masyarakat tidak hanya memerlukan pengetahuan, sikap positif dan dukungan fasilitas saja dalam berperilaku sehat, melainkan diperlukan juga perilaku contoh (acuan) dari para tokoh masyarakat, tokoh agama, para petugas, terutama petugas kesehatan (Notoatmodjo, 2007).

\section{Analisis Bivariat}

Berikut ini tabel analisis bivariat, hubungan pengetahuan dengan kepemilikan jamban sehat di RT. 01 Kelurahan Alalak Utara wilayah kerja Puskesmas Alalak Tengah Kota Banjarmasin.

Tabel 3. Hubungan Pengetahuan Dengan Kepemilikan Jamban Sehat

\begin{tabular}{lcccccccc}
\hline \multirow{2}{*}{ Pengetahuan } & \multicolumn{2}{c}{ Jamban sehat } & \multicolumn{2}{c}{ TMS } & \multicolumn{2}{c}{ Tidak Memiliki } & \multicolumn{2}{c}{ Jumlah } \\
\cline { 2 - 10 } & $\mathbf{n}$ & $\mathbf{0}$ & $\mathbf{N}$ & $\mathbf{0}$ & $\mathbf{n}$ & $\mathbf{0}$ & $\mathbf{n}$ & $\mathbf{\%}$ \\
\hline Baik & 15 & 51.7 & 8 & 27.6 & 6 & 20.7 & 29 & 100 \\
Cukup & 3 & 9.1 & 18 & 54.5 & 12 & 36.4 & 33 & 100 \\
Kurang & 0 & 0 & 0 & 0 & 3 & 100 & 3 & 100 \\
Total & $\mathbf{1 8}$ & $\mathbf{2 7 . 7}$ & $\mathbf{2 6}$ & $\mathbf{4 0}$ & $\mathbf{2 1}$ & $\mathbf{3 2 , 3}$ & $\mathbf{6 5}$ & $\mathbf{1 0 0}$ \\
\hline
\end{tabular}


Tabel 4. Hubungan Sikap Dengan Kepemilikan Jamban sehat

\begin{tabular}{|c|c|c|c|c|c|c|c|c|c|}
\hline \multirow{2}{*}{ Sikap } & \multicolumn{2}{|c|}{ Jamban Sehat } & \multicolumn{2}{|c|}{ TMS } & \multicolumn{2}{|c|}{ Tidak Memiliki } & \multicolumn{2}{|c|}{ Jumlah } & \multirow{2}{*}{$\begin{array}{c}\text { P value } \\
0,000\end{array}$} \\
\hline & $\mathrm{n}$ & $\%$ & $\mathrm{n}$ & $\%$ & $\mathrm{n}$ & $\%$ & $\mathrm{n}$ & $\%$ & \\
\hline Positif & 17 & 42.5 & 17 & 42.5 & 6 & 12.9 & 40 & 100 & \\
\hline Negatif & 1 & 4 & 9 & 36 & 15 & 60 & 25 & 100 & \\
\hline Total & 18 & 27.7 & 26 & 40 & 21 & 32.3 & 65 & 100 & \\
\hline
\end{tabular}

Tabel 5. Hubungan Tingkat Pendidikan Dengan Kepemilikan Jamban sehat

\begin{tabular}{lcccccccc}
\hline \multirow{2}{*}{ Tingkat Pendidikan } & \multicolumn{2}{c}{ Jamban Sehat } & \multicolumn{2}{c}{ TMS } & \multicolumn{2}{c}{ Tidak Memiliki } & \multicolumn{2}{c}{ Jumlah } \\
\cline { 2 - 9 } & $\mathbf{n}$ & $\mathbf{0}$ & $\mathbf{n}$ & $\mathbf{0}$ & $\mathbf{n}$ & $\mathbf{\%}$ & $\mathbf{n}$ & $\mathbf{\%}$ \\
\hline Dasar & 6 & 13 & 22 & 47.8 & 18 & 39.1 & 46 & 100 \\
Menengah & 10 & 58.8 & 4 & 23.5 & 3 & 17.5 & 17 & 100 \\
Tinggi & 2 & 100 & 0 & 0 & 0 & 0 & 2 & 100 \\
Total & $\mathbf{1 8}$ & $\mathbf{2 7 . 7}$ & $\mathbf{2 6}$ & $\mathbf{4 0}$ & $\mathbf{2 1}$ & $\mathbf{3 2 . 3}$ & $\mathbf{6 5}$ & $\mathbf{1 0 0}$ \\
\hline
\end{tabular}

Tabel 4 menunjukkan responden dengan sikap positif 40 responden memiliki jamban sehat 17 responden (42,5\%), memiliki jamban tidak memenuhi syarat sebanyak 17 responden $(42,5 \%)$, tidak memiliki jamban 6 responden (12,9\%). 25 responden dengan sikap negatif tidak memiliki jamban sebanyak 15 responden (60\%), memiliki jamban tidak memenuhi syarat 9 responden (36\%), dan memiliki jamban sehat 1 responden (4\%).

Hasil uji Chi Square dengan tingkat kepercayaan 95\% diperoleh Nilai $p$-value $=0,000<$ 0,05 yang berarti Hipotesis diterima. Hasil penelitian menyatakan terdapat hubungan yang signifikan antara Sikap dengan Kepemilikan Jamban Sehat Di RT. 01 Kelurahan Alalak Utara wilayah kerja Puskesmas Alalak Tengah Kota Banjarmasin. Sejalan dengan penelitian yang dilakukan Otik Widyastutik (2016) dengan judul Faktor Yang Berhubungan Dengan Kepemilikan Jamban Sehat di Desa Malikian, Kalimantan Barat dengan hasil penelitian menunjukkan bahwa ada hubungan antara Sikap dengan kepemilikan jamban sehat (p-value 0,037$)$.

Menurut Notoatmodjo (2011) Sikap merupakan reaksi atau respon seseorang yang masih tertutup terhadap suatu stimulus atau objek, sikap itu tidak dapat langsung dilihat, tetapi hanya dapat ditafsirkan terlebih dahulu dari perilaku yang tertutup. Sikap secara nyata menunjukkan konotasi adanya kesesuaian reaksi terhadap stimulus tertentu.
Dalam kehidupan sehari-hari merupakan reaksi yang bersifat emosional terhadap stimulus sosial.

Tabel 5 menunjukkan responden dengan tingkat pendidikan dasar sebanyak 46 responden, yang memiliki jamban tidak memenuhi syarat sebanyak 22 responden $(47,8 \%)$, tidak memiliki jamban sebanyak 18 responden $(39,1 \%)$, dan memiliki jamban sehat 6 responden (13\%). Kemudian 17 responden dengan tingkat pendidikan menengah memiliki jamban sehat sebanyak 10 responden (58,8\%), memiliki jamban tidak memenuhi syarat 4 responden $(23,5 \%)$, tidak memiliki jamban berjumlah 3 responden (17,5\%). Sedangkan responden dengan Tingkat pendidikan tinggi yang memiliki jamban sehat berjumlah 2 responden (100\%).

Berdasarkan dari hasil uji Chi Square dengan uji alternatif penggabungan sel dan terbentuk suatu tabel B $\times$ K yang baru. Diperoleh uji hipotesis dengan tingkat kepercayaan 95\% yaitu nilai $p$-value $=0,000<$ 0,05 yang berarti Hipotesis diterima. Hasil penelitian menyatakan terdapat hubungan yang signifikan antara Tingkat Pendidikan Dengan Kepemilikan Jamban Sehat Di RT. 01 Kelurahan Alalak Utara Tahun wilayah kerja Puskesmas Alalak Tengah Kota Banjarmasin. Sejalan dengan penelitian Ganda Sunaryo Putra dan Selviana (2017) tentang faktorfaktor yang berhubungan dengan kepemilikan jamban sehat di Desa Empakan Kecamatan Kayan Hulu menunjukkan ada hubungan yang bermakna 
Tabel 6. Hubungan Status Ekonomi Dengan Kepemilikan Jamban sehat

\begin{tabular}{|c|c|c|c|c|c|c|c|c|c|}
\hline \multirow{2}{*}{ Status Ekonomi } & \multicolumn{2}{|c|}{ Jamban Sehat } & \multicolumn{2}{|c|}{ TMS } & \multicolumn{2}{|c|}{ Tidak Memiliki } & \multicolumn{2}{|c|}{ Jumlah } & \multirow{3}{*}{$\begin{array}{c}\text { p-value } \\
0,000\end{array}$} \\
\hline & $\mathrm{N}$ & $\%$ & $\mathrm{~N}$ & $\%$ & $\mathrm{n}$ & $\%$ & $\mathrm{n}$ & $\%$ & \\
\hline Penghasilan $\geq$ UMK & 16 & 76.2 & 5 & 23.8 & 0 & 0 & 21 & 100 & \\
\hline Penghasilan < UMK & 2 & 4.5 & 21 & 47.7 & 21 & 47.7 & 44 & 100 & \\
\hline Total & 18 & 27.7 & 26 & 40 & 21 & 32,3 & 65 & 100 & \\
\hline
\end{tabular}

Tabel 7. Hubungan Peran Petugas Kepemilikan Jamban sehat

\begin{tabular}{|c|c|c|c|c|c|c|c|c|c|}
\hline \multirow{2}{*}{ Peran Petugas } & \multicolumn{2}{|c|}{ Jamban sehat } & \multicolumn{2}{|c|}{ TMS } & \multicolumn{2}{|c|}{ Tidak Memiliki } & \multicolumn{2}{|c|}{ Jumlah } & \multirow{2}{*}{$\begin{array}{r}\text { p-value } \\
0,07\end{array}$} \\
\hline & $\mathrm{n}$ & $\%$ & $\mathrm{n}$ & $\%$ & $\mathrm{n}$ & $\%$ & $\mathrm{~N}$ & $\%$ & \\
\hline Aktif & 9 & 47.4 & 5 & 26.3 & 5 & 26.3 & 19 & 100 & \\
\hline Tidak Aktif & 9 & 19.6 & 21 & 45.7 & 16 & 34.8 & 46 & 100 & \\
\hline Total & 18 & 27.7 & 26 & 40 & 21 & 32.3 & 65 & 100 & \\
\hline
\end{tabular}

antara tingkat pendidikan dengan kepemilikan jamban sehat ( $p$-value 0,000).

Semakin rendah pendidikan masyarakat akan lebih sulit menyerap informasi bagaimana jamban yang memenuhi syarat sehat. Sehingga masyarakat masih banyak yang belum memiliki jamban sehat atau memenuhi syarat kesehatan. Semakin tinggi pendidikan seseorang maka semakin tinggi kesadaran yang berperan serta dalam upaya pencegahan penyakit. Kategori pendidikan berdasarkan keputusan menteri pendidikan nasional adalah tingkat dasar yaitu pendidikan sekolah dasar dan sekolah menengah pertama, dan tingkat pendidikan tinggi yaitu sekolah menengah keatas akademi dan perguruan tinggi (UU No 20, 2003).

Tabel 6. menunjukkan responden dengan status ekonomi <UMK atau berpenghasilan rendah sebanyak 44 responden, memiliki jamban tidak memenuhi syarat sebanyak 21 responden $(47,7 \%)$, tidak memiliki jamban sebanyak 21 responden $(47,7 \%)$, dan memiliki jamban sehat 2 responden $(4,5 \%)$. Responden dengan status ekonomi $\geq \mathrm{UMK}$ atau berpenghasilan tinggi sebanyak 21 responden, yang memiliki jamban sehat berjumlah 16 responden $(76,2 \%)$, dan yang memiliki jamban tidak memenuhi syarat 5 responden $(23,8 \%)$.
Hasil uji Chi Square dengan tingkat kepercayaan 95\% diperoleh Nilai p-value $=0,000<$ 0,05 yang berarti Hipotesis diterima. Hasil penelitian menyatakan terdapat hubungan yang signifikan antara Status Ekonomi dengan Kepemilikan Jamban Sehat Di RT. 01 Kelurahan Alalak Utara wilayah kerja Puskesmas Alalak Tengah Kota Banjarmasin.

Hasil penelitian ini menunjukkan tingginya masyarakat dengan status ekonomi rendah. Status ekonomi seseorang untuk memenuhi kebutuhan hidup sangat berpengaruh pada fasilitas kesehatan mereka khususnya di dalam rumahnya akan terjamin, misalnya dalam penyediaan jamban keluarga. Sejalan dengan penelitian Fera Novitry dan Rizka Agustin (2017) dengan judul determinan kepemilikan jamban sehat di Desa Sukomulyo Martapura Palembang dengan Hasil penelitian menunjukkan ada hubungan yang bermakna antara pendapatan keluarga ( $p$ value 0,001) dengan kepemilikan jamban sehat.

Tabel 7 menunjukkan responden menyatakan peran petugas tidak aktif sebanyak 46 responden, memiliki jamban tidak memenuhi syarat berjumlah 21 responden $(45,7 \%)$, tidak memiliki jamban 16 responden $(34,8 \%)$, dan memiliki jamban sehat 9 responden $(19,6 \%)$. Sedangkan 19 responden yang menyatakan peran petugas Aktif yang memiliki jamban sehat sebanyak 9 responden $(47,4 \%)$, yang 
memiliki jamban tidak memenuhi syarat 5 responden $(26,3 \%)$, dan tidak memiliki jamban 5 responden $(26,3 \%)$.

Hasil uji Chi Square dengan tingkat kepercayaan 95\% diperoleh Nilai P $=0,07>0,05$ yang berarti Hipotesis ditolak. Hasil penelitian menyatakan tidak terdapat hubungan yang signifikan antara Peran Petugas dengan Kepemilikan Jamban Sehat Di RT. 01 Kelurahan Alalak Utara wilayah kerja Puskesmas Alalak Tengah Kota Banjarmasin. Peran petugas tidak ada hubungan yang bermakna dengan kepemilikan jamban sehat, jika peran petugas lebih aktif lagi dalam melakukan penyuluhan dan memberi informasi kepada masyarakat tentang tata cara hidup sehat dan pengetahuan masyarakat tentang jamban sehat maka banyak masyarakat yang mengerti akan pentingnya memiliki jamban sehat dan tergerak untuk memiliki jamban yang lebih memenuhi syarat sehat.

Menurut Notoatmodjo (2007), salah satu unsur yang berperan dalam percepatan pembangunan kesehatan adalah tenaga kesehatan yang bertugas di sarana pelayanan kesehatan di masyarakat. Sejalan dengan penelitian Otik Widyastuti (2016) tentang faktor yang berhubungan dengan kepemilikan jamban sehat di Desa Malikian, Kalimantan Barat yaitu tidak terdapat hubungan yang bermakna antara peran petugas dengan kepemilikan jamban sehat ( $p$-value 1.000).

\section{KESIMPULAN}

Ada hubungan yang signifikan antara pengetahuan ( $p$ value 0,001$)$, sikap ( $p$ value 0,000$)$, tingkat pendidikan ( $p$ value 0,000 ), status ekonomi ( $p$ value 0,000 ) dengan kepemilikan jamban sehat, tidak ada hubungan antara peran petugas ( $p$ value 0,07 ) dengan kepemilikan jamban sehat. Disarankan agar masyarakat bersama-sama petugas kesehatan lebih berperan aktif dalam menjaga kesehatan lingkungan yaitu dengan cara membangun jamban sehat dan meningkatkan kesadaran akan pentingnya memiliki jamban sehat.

\section{DAFTAR PUSTAKA}

Azwar, Saiffudin. 2003. Metode Penelitian. Cetakan ke-enam, Yogyakarta: Pustaka Pelajar.
Kementrian Kesehatan, 2016. Profil Kesehatan tahun 2015 di Indonesia. Jakarta: Kemenkes RI.

Putra, GS, dan Selviana. 2017. Faktor Faktor Yang Berhubungan Dengan Kepemilikan Jamban Sehat Kayan Hulu [Online] From (http://openjurnal.unmuhpnk.ac.id/index.ph $\mathrm{p} / \mathrm{JKMK} /$ article/download/866/690) diakses tanggal 15 Mei 2018.

Notoatmodjo, S. 2011. Kesehatan Masyarakat Ilmu dan Seni. Jakarta : Rineka Cipta.

2007. Pendidikan Dan Perilaku Kesehatan. Jakarta : Rineka Cipta.

Novitry, Fera., Agustin, Rizka. (2017). Determinan Kepemilikan Jamban Sehat Di Desa Sukomulyo Martapura Palembang [Online]. From

(http://ejournal.stikesaisyah.ax.id/index.php /jika/) diakses tanggal 25 April 2018.

Profil Puskesmas Alalak Tengah Tahun 2017.

Profil Kelurahan Alalak Utara Tahun 2017.

Undang-undang Sistem Pendidikan Nasional. 2014 [Online] From (https://www.komisiinformasi.go.id/regulasi /download/id/101) diakses tanggal 15 mei 2018.

Widyastuti, Otik. 2016 Faktor Yang Berhubungan Dengan Kepemilikan Jamban Sehat di Desa Malikian, Kalimantan Barat [Online] From (neliti.com/media/publications/14508-IDfaktor-faktor-yang-berhubungan-dengankepemilikan-jamban-keluarga-di-desasipang.pdf) diakses tanggal 26 April 2018. 